\title{
The Significance of Geographic and Programmatic Context in Developing Historical Case Studies in Social Foundations in Teacher Education
}

\section{Isaac Gottesman and Michael Bowman}

Course: School \& Society graduate course in the Elementary Teacher Education Master of Teaching (MIT) program

Institution: University of Washington, Seattle

Course: Social Foundations of Education in the United States undergraduate course, required course in all ISU teacher certification programs

Institution: Iowa State University

In the summer of 2008, we met at an alehouse in Columbia City, a rapidly gentrifying neighborhood on Seattle's south side, to begin conceptualizing and designing a School \& Society class we were teaching that fall in a Master of Teaching (MIT) elementary teacher education program at the University of Washington (UW) in Seattle. One of us (Isaac) was working on a dissertation and was the instructor of record, while the other (Michael) was transitioning from master's to doctoral student, and was the teaching assistant. This was the first preservice teacher education social foundations course either of us had taught. The experience of working together on that course has led to several years of collaborative thinking about social foundations in teacher education, including developing what we call a "place-conscious approach" -an approach that grounds the political and normative questions at the heart of social foundations in the history of places in which preservice teachers learn to teach. ${ }^{1}$

Case study is central to our thinking. The history of the places we study - cities, neighborhoods, schools-are approached as cases, spaces

Isaac Gottesman and Michael Bowman are assistant professors in the School of Education at Iowa State University.

${ }^{1}$ For an earlier iteration of our thinking, see Michael Bowman and Isaac Gottesman, "Why Practice-Centered Teacher Education Programs Need Social Foundations," Teachers College Record (March 22, 2013), http://www.tcrecord.org, ID number: 17066. 
in which teaching and learning are simultaneously bound by geography and embedded in broader cultural, economic, political, and social contexts. Through studying place as a case, we believe that students begin to see how teachers participate in and are ultimately coconstructors of the concrete ideological and material manifestations of the more abstract contextual forces that push and pull the experiences of individuals and social groups in schools.

In this essay, we focus on the context-dependent nature of this approach. We do this by juxtaposing our use of a place-conscious approach in the geographic and programmatic context in which it was conceptualized with our use of a place-conscious approach in a radically different context. The first context is the UW in Seattle, where we began thinking about these issues together, and where one of us remained until the summer of 2015. The second context is Iowa State University (ISU) in Ames, where one of us took a faculty position in Fall 2010 and where the other joined as a faculty member in Fall 2015. For us, the sharp contrast between these two contexts illuminates the importance of thinking deeply about geographic and programmatic context when developing coursework that claims to be place-conscious. ${ }^{2}$

Notably, in all of our teaching, we take the sociocultural learning position that meaning in the classroom is coconstructed between students and teachers through dialogue and collective inquiry. ${ }^{3}$ For us, taking a place-conscious approach thus requires continuously reflecting upon the question: How is the instructor situated in the context of teaching and learning, both in relation to students and the topics and "place" under inquiry? Just as a central element of our teaching is having students unpack and engage their own identities and experiences as part of a process of critically reflecting on education and the social world, we also unpack and engage our identities and experiences with our students. In our case, both of us are white, male, heterosexual, and upper middle class; one of us (Isaac) is Jewish and the other (Michael) was raised Protestant. Also, neither of us grew up in the places we teach: One of us (Isaac) is from Eugene, Oregon, while the other (Michael) is from Louisville, Kentucky. Although not discussed in detail in this essay, these identities and experiences shape our thinking about the world, and most certainly shape our pedagogy.

${ }^{2}$ Though written with a focus on preservice teacher education, we believe the issues of geographic context and programmatic context are relevant in all place-based case study approaches. In this forum, for instance, these issues are notably central to the type of work undertaken by Jack Daugherty, Ansley Erickson, John Hale, and Heather Lewis.

${ }^{3}$ For further discussion, see Bowman and Gottesman, "Why Practice-Centered Teacher Education Programs Need Social Foundations." 


\section{Context One: University of Washington in Seattle}

The elementary and secondary teacher education programs at the UW are fifteen-month, MIT, cohort-based programs that operate as distinct entities. The cohort in each program has around sixty students, most from the Seattle area; both cohorts are increasingly racially and ethnically diverse, with students primarily being upper middle class, often having completed their bachelor's degrees at highly prestigious public and private colleges and universities. In elementary education, most students are female. Some students in both programs openly identify as LGBTQ (Lesbian, Gay, Bisexual, Transgender, and/or Questioning). ${ }^{4}$ Though the programs are distinct, both programs are grounded in the literature in practice-centered teacher education. ${ }^{5}$ As with practicecentered programs at other institutions, students spend significant time in the field, including often taking methods classes in schools. This programmatic context afforded us an incredible opportunity to think about preparing preservice teachers in a specific geographic context. ${ }^{6}$

Two clusters of broad normative and historical questions framed our initial course and continued to frame the course in following years:

What has been the purpose of public schooling? Who has decided? Who should decide?

What has been the role of the teacher both inside and outside of school? Who has decided? Who should decide?

In 2013, Michael and a different coinstructor added a third cluster of questions in response to student feedback and a series of individual and focus group interviews. ${ }^{7}$ This cluster was organized around the question: How have children experienced the schooling created for them?

${ }^{4}$ Each program offers two sections of a foundations course. One of us (Isaac) has taught Elementary and Secondary sections while the other (Michael) has taught several sections of Elementary. Individual instructors determine course syllabi for foundations in both programs.

${ }^{5}$ The UW is also a central site for the development of practice-centered teacher education scholarship. For further discussion on practice-centered teacher education, see Kenneth Zeichner, "The Turn Once Again Toward Practice-Based Teacher Education," Fournal of Teacher Education 63, no. 5 (2012): 376-82.

${ }^{6}$ Preservice teachers complete practicum and student teaching in the Seattle area, and frequently in Seattle public schools. This is also the area in which most candidates seek in-service positions.

${ }^{7}$ The coinstructor in this course was Kate Napolitan. These individual and group interviews were part of a Spencer Foundation Small Grant-funded programmatic research project at the UW concerned with the implementation of a Community-FamilyPolitics strand within teacher education. This work was done in collaboration with the Multicultural Education Rights Alliance (McERA). Publications based on this work are currently under review. For a brief description and its potential relation to social foundations, see James Fraser, "HES Presidential Address: The Future of the Study of Our Educational Past-Whither the History of Education?" History of Education Quarterly 55, no. 1 (February 2015): 27. 
In its most recent iteration, the course readings, field experiences, student-led Socratic seminars, and conversations with families and community leaders emplace these questions within Seattle, while simultaneously recognizing that larger cultural, economic, political, and social forces always shape and constrain local actions. The course, taught in a ten-week quarter, moves briskly and chronologically. It begins with a section of Coll Thrush's Native Seattle about the long-and continuing-history of indigenous and white contact in the region. ${ }^{8}$ In the following class session, we hold class at the Duwamish Longhouse and Cultural Center, and learn from tribal members, cultural teachers, and (sometimes) youth about Duwamish history and their continued fight for federal recognition.

The course readings then move into the Progressive Era, when white, Chinese, and Japanese population increases forced Seattle schools to grow into a system. Bryce Nelson's Good Schools, Shelley Sang-Hee Lee's Claiming the Oriental Gateway, and Yoon Pak's Wherever I Go, I Will Always Be a Loyal American raise issues of pedagogical and administrative progressivism; white racial anxiety and teacher agency within the context of West Coast anti-Japanese organizing; racialized residential segregation and neighborhood schools; and Americanization and interculturalism. ${ }^{9}$ During class sessions, we draw heavily on the Seattle Civil Rights \& Labor History Project, an excellent site for oral histories and primary source documents related to racial segregation and civil rights activism. We use it during this part of the course to examine historical demographic maps and the texts of hundreds of racial covenants throughout the city. ${ }^{10}$

At that point in the quarter, all courses in the teacher education program relocate to an elementary school in the historically and culturally rich South Park neighborhood of Seattle. Using archival photographs and a school district history of the school building, we take a visual historical tour of the neighborhood before being led on a neighborhood tour by local residents. Because the neighborhood is in proximity to Boeing's main Seattle plant, which brought tens of thousands of workers to Seattle during World War II, it provides a good entrée into discussions of the long civil rights movement. We read the text

${ }^{8}$ Coll Thrush, Native Seattle: Histories from the Crossing-Over Place (Seattle, WA: University of Washington Press, 2009).

${ }^{9}$ Bryce Nelson, Good Scbools: The Seattle Public Scbool System, 1901-1930 (Seattle, WA: University of Washington Press, 1988); Shelley Sang-Hee Lee, Claiming the Oriental Gateway: Prewar Seattle and Fapanese America (Philadelphia, PA: Temple University Press, 2012); and Yoon Pak, Wherever I Go, I Will Always Be a Loyal American: Schooling Seattle's 7apanese Americans during World War II (New York: RoutledgeFalmer, 2002).

10 "Segregated Seattle," Seattle Civil Rights \& Labor History Project, http://depts.washington.edu/civilr/segregated.htm. 
of the Brown decision alongside descriptions of various responses to it from across the country and a section of Seattle in Black and White on the Congress of Racial Equality (CORE) organizing around Seattle school segregation, its school boycott, and its creation of Freedom Schools. ${ }^{11}$ We end the course with readings about Seattle's desegregation and busing plans during the 1960s and 1970s; the 2007 Parents Involved in Community Schools vs. Seattle School District No. 1 case, which prohibited school districts from considering race in school assignment; and a panel discussion of Seattle civil rights leaders past and present.

Because we are working with teachers, we envision the course as one that promotes continual inquiry and reflection upon the above normative and historical questions, that provides tools for future inquiry, and that models a place-conscious pedagogy that we want them to take with them into their own classrooms.

One of the joys of taking a place-conscious approach to foundations is that it often has the effect of making everyday landscapes strange. For our students from Seattle, few of whom are American Indian, to look at the maps provided by Coll Thrush of indigenous places of significance-with their Lushootseed place names-adds another layer to their understanding of Seattle. To learn of the city's nativist and segregationist history challenges some students' understandings, especially the understandings of white students, most of whom have not engaged in such deep conversations about race, of the cosmopolitan claims of city and school district leaders. To hear about the ways schools have been, and continue to be, used as sites of social reproduction and social struggle can elevate the significance of the institution and the importance of the teacher.

\section{Context Two: Iowa State University in Ames}

The teacher education programs at ISU are radically different from the teacher education programs at the UW. Compared to the small graduate certification programs at the UW, ISU has nearly a thousand students in an array of predominantly undergraduate teacher education programs. Due to its size, ISU's programs are more a collection of certification areas bound by a compilation of courses and field experiences than a coherent and aligned program, as is the case at the UW. Almost all students in ISU's certification programs are white, predominantly middle or working class, with many being first- or second-generation

${ }^{11}$ Joan Singler, Jean Durning, Bettlylou Valentine, and Maid Adams, Seattle in Black and White: The Congress of Racial Equality and the Fight for Equal Opportunity (Seattle, WA: University of Washington Press, 2011). 
college students. About 95 percent of the students in elementary education, which alone is over five hundred students in any given year, are female. A tiny fraction of students openly identify as LGBTQ. Most students are from Iowa, both urban and rural, though increasing numbers of students come from surrounding states, especially the suburbs of large cities, such as Minneapolis-St. Paul, Kansas City, and Chicago. The programs also include a large number of community college transfers. ${ }^{12}$

One of four courses that all students receiving certification at ISU are required to take is Social Foundations of Education in the United States. ${ }^{13}$ Several sections of the course are offered each semester; in Fall 2015 there are eleven sections (thirty to thirty-five students per section) with another ten sections likely to be offered in Spring 2016. Further, most students taking this course are first- or second-year college students, with this usually being their first course in education, and in the case of first-year students taking the course Fall semester, one of their first ever college courses.

With students potentially teaching a range of subjects, in a range of locations (both in practicum/student teaching and as in-service teachers), and coming with limited, if any, college-level coursework experience, it is difficult to be place-conscious in the same way that it was at the UW. For example, an initial attempt was made to create case studies of four different contexts that included a range of the types of places students would be working in as preservice and potentially as in-service teachers: a "case of" schooling in a large city (Chicago, which is six hours away), a medium-sized city (Des Moines, which is thirty-five minutes away), a small city (Ames), and a small town (Gilbert, which is fifteen minutes away). This approach proved too ambitious, partly because of the expertise and time commitment required on the part of the instructor to develop four robust cases. Also, in order to create alignment across sections, the core syllabus needed to be accessible to four or five different instructors each semester, with instructors, both graduate students and lecturers who do not necessarily have expertise in the history of education, often rotating in and out each year. Programmatic context necessitated balancing an ideal vision of the course with institutional constraints.

The next move was to focus the core syllabus on broader issues and themes. This made it possible for several instructors, of varying expertise, to teach the course while continuing to carve curricular space

${ }^{12}$ As is the case with all large teacher education programs, cohesion, even if desired, is rather difficult to realize due to the sheer volume of students, faculty and staff, and the numerous moving parts, such as placements.

${ }^{13}$ The other three are Educational Technology, Special Education, and Multicultural Education. 
for more specific place-based study in individual sections. In its current iteration, during the first part of the course (two weeks) students reflect on their own schooling experiences and thoughts about the purpose of schooling by, for instance, writing and sharing educational autobiographies and reading Luis Moll's work on funds of knowledge. ${ }^{14}$ This move reflects the sociocultural framing we describe in the introduction of the essay. During this section, the instructor also talks with the class about their own schooling experiences. These conversations form the foundation for future dialogue in the course around issues of race and ethnicity, political economy and social class, gender and sexuality, and ability.

In the second part of the course (four weeks), we do a broad overview of the history of schooling in the United States using John Rury's interpretive history of schooling, Education and Social Change, as a grounding text, and coupling it with a range of primary source documents that illuminate the gendered, political, economic, racialized, and legal structures that have impacted schools and teachers throughout history. ${ }^{15}$ Documents used include an essay by Catherine Beecher on the education of female teachers, the opening essay in George Counts's Dare the School Build a New Social Order, the Brown decision, and selections of the decision in Plyler $v$. Doe. ${ }^{16}$

In the third part of the course (six weeks), we focus on four lenses to see schooling - race and ethnicity, political economy and social class, gender and sexuality, and ability-by reading and discussing a range of scholarly literature, such as selections from Dorothy Roberts's Fatal Invention; Beth Rubin's work on tracking; Richard Rothstein's work on social class; Arnold Grossman's work on the experiences of GLBTQ high school students; and Roey Ahrum, Edward Fergus, and Pedro Noguera's research on disproportionality. ${ }^{17}$ In the fourth section (two

${ }^{14}$ Luis C Moll, Cathy Amanti, Deborah Neff, and Norma Gonzalez, "Funds of Knowledge for Teaching: Using a Qualitative Approach to Connect Homes and Classrooms," Theory Into Practice 31, no. 2 (1992): 132-41.

${ }^{15}$ John Rury, Education and Social Change: Contours in the History of American Schooling (New York: Routledge, 2015).

${ }^{16}$ Catherine E. Beecher, "An Essay on the Education of Female Teachers for the United States," in The Scbool in the United States: A Documentary History, ed. James E. Fraser (New York: Routledge, 2010), 57-60; George S. Counts, Dare the Scbool Build a New Social Order? (Carbondale: Southern Illinois University Press, 1978); Brown v. Board of Education of Topeka, 347 U.S. 483 (1954); and "Plyler v. Doe, 1982," in Latino Education in the United States: A Narrated History from 1513-2000, ed. Victoria-Maria MacDonald (New York: Palgrave Macmillan, 2004), 286-93.

${ }^{17}$ Dorothy Roberts, Fatal Invention: How Science, Politics, and Big Business Re-create Race in the Twenty-First Century (New York: New Press, 2011); Beth Rubin, "Detracking in Context: How Local Constructions of Ability Complicate Equity-Geared Reform," Teacbers College Record 110, no. 3 (2008): 646-99; Richard Rothstein, "Why Children from Lower Socioeconomic Classes, on Average, Have Lower Academic Achievement 
weeks), we focus on federal and state education policy with Diane Ravitch's Reign of Error as an anchor text. ${ }^{18}$ The final week of class is for debrief and time to work on final papers, which also serve as an artifact for the teacher education program portfolio. ${ }^{19}$

Within this course framework, individual instructors draw from the historical and contemporary landscape of school and society in Iowa. In class, for instance, students examine Iowa-specific historical maps and documents; read text from the Iowa Core (alongside the Common Core); dissect historical and contemporary state and local demographic data; read local housing marketing websites as part of a discussion about housing segregation in Des Moines; read school, district, and state testing data; review district and school websites; and engage with a range of other primary source material, historical and contemporary, in order to make the more abstract cultural, economic, historical, political, and social ideas and contexts we use to frame the course more concrete. As with the foundations class in Seattle, the place-conscious approach serves to make the familiar strange, especially for students from Iowa.

In addition to learning to navigate programmatic differences, being in Iowa has raised significant geographic issues about how one develops a place-conscious approach in a context with little secondary source material and few easily accessible primary source archives (online or otherwise). Though a decent amount of primary source material has been accumulated, it is still a relatively thin amount of material for students to engage, especially when compared to the rich trove of resources readily available in Seattle. Fortunately, with both of us being in Iowa, and the newest arrival being a historian of the local (wherever that local is), we should be able to more rapidly accumulate resources. ${ }^{20}$

than Middle-Class Children," in Closing the Opportunity Gap: What America Must Do to Give Every Child an Even Chance, eds. Prudence L. Carter and Kevin G. Welner (New York: Oxford University Press, 2013), 61-74; Arnold H. Grossman, Adam P. Haney, Perry Edwards, Edward J. Aless, Maya Ardon, and Tamika Jarrett Howell, "Lesbian, Gay, Bisexual, and Transgender Youth Talk About Experiencing and Coping with School Violence: A Qualitative Study," Fournal of LGBT Youtb 6, no. 1 (2009): 24-46; and Roey Ahram, Edward Fergus, and Pedro Noguera, "Addressing Racial/Ethnic Disproportionality in Special Education: Case Studies of Suburban School Districts," Teachers College Record 113, no. 10 (2013): 2233-66.

${ }^{18}$ Diane Ravitch, Reign of Error: The Hoax of the Privatization Movement and the Danger to America's Public Scbools (New York: Vintage, 2013).

${ }^{19}$ In an attempt to leverage individual instructor expertise and to foster an environment of collaboration and dialogue across sections, instructors meet regularly to reflect on student work, share instructional activities, and more generally discuss the course. Course instructors over the past few years have thus been instrumental in improving the class and deserve recognition: Chuck Achter, Malika Butler, Ellen Fairchild, Jennifer Farley, Tami Moen, and Sam Von Gillern.

${ }^{20}$ In addition to the valuable contributions of other course instructors, we are also collaborating with a faculty member in elementary social studies education, Katy 


\section{Conclusion}

If we start from the premise that place matters, a focus on both geographic and programmatic context opens up a world of questions that force a powerful examination of any place-based curricular approach, especially in teacher education.

Geographic context raises questions about existing resources. What is the extent of the secondary literature on your geographic context, and what is the relative need (as well as desire) on the part of the instructor, and potentially students, to engage in the collection of primary source documents and perhaps the creation of secondary literature? Are there archives readily available with primary source resources, including online sources that students and instructors can easily access? In terms of resources, taking a place-conscious approach in New York City, Chicago, or even Seattle is very different than taking a placeconscious approach in Ames, Iowa. Narratives can always be created, but it is helpful to have primary source archives and a range of secondary sources readily available. Furthermore, if your own work is not focused on creating local narratives (as is the case with one of us), taking a place-conscious approach becomes that much more difficult absent existing resources.

Programmatic context raises questions about how a course is situated in a broader program, such as preservice teacher education. Is it an undergraduate or graduate program? Where does the course fit in the teacher education program, including what courses have students taken prior to the foundations course and what program-specific field experiences have they had in schools or communities? It also raises questions about program coherence and the degree to which teacher education is really a collaborative endeavor across courses, field experiences, and other program requirements: Is what you are doing in the foundations course connected to anything else happening in the program, and if so, how, and if not, to what degree can you work with others to create cohesion?

Finally, the programmatic context determines practicum and student-teaching placements and probably says something about where students are expecting or are likely to find in-service teaching positions. Programmatic context thus tells us something significant about the geographic places that may be used as cases. At the UW, we knew most of our preservice teachers were going to be teaching in the Seattle area. At ISU, our preservice teachers end up all over Iowa, the Midwest, and often far outside the region.

Swalwell, who taught a class in Summer 2015 on Teaching and Learning Iowa History: Iowans and the Civil Rights Movement. 
We believe that a place-conscious approach is desirable in all teacher education programs and that the use of a case study can be an invaluable tool for teaching history. However, what any of this looks like in the classroom is going to depend in large part on your own identity, experiences, and expertise, and where you teach, both geographically and programmatically. 